\title{
An Active Contributor: Dr. Lindberg and NLM's Historical Programs and Services
}

\author{
John PARASCANDOLA Ph.D. ${ }^{1}$ \\ Affiliate, Department of History, University of Maryland College Park
}

\begin{abstract}
Donald A.B. Lindberg M.D.'s interests extended far beyond his scientific expertise into the arts and humanities, as evidenced, for example, by his love of opera, his talents in photography, and his affection for history. It is therefore not surprising that he had a strong interest in the National Library of Medicine's historical programs and services, going beyond supporting these activities to becoming actively involved in some of them. The subject of this essay is Dr. Lindberg's contributions to these programs and services, which may be grouped under three main headings: placing greater emphasis on more contemporary history, promoting the digitization of historical materials to increase access, and enhancing outreach through an exhibition program.
\end{abstract}

Keywords. History of medicine, history, historical collections, digitization, exhibitions, U.S. National Library of Medicine, Donald A.B. Lindberg, M.D.

\section{Introduction}

The interests of Donald A. B. Lindberg M.D., Director, U.S. National Library of Medicine (NLM), extended far beyond his scientific expertise into the arts and humanities, as evidenced, for example, by his love of opera, his talents in photography, and his affection for history. One reflection of his broader interest was his decision to sponsor and help organize three symposia on medicine and the arts at NLM, beginning with a program on "Medicine and the Arts: Two Faces of Humanity" on April 12, 1986 as part of the Library's Sesquicentennial Celebration. This event was followed by symposia on "Images of the Health Professions in the Popular Arts" in 1988 and "The Medicinal Muses: The Therapeutic Value of the Arts" in 1990. Dr. Lindberg also arranged for several exhibitions on medicine and visual art during his tenure.

It is therefore not surprising that Dr. Lindberg had a strong interest in the NLM's historical programs and services, going beyond supporting these activities to becoming actively involved in some of them. The subject of this essay is his contribution to these programs and services, which may be grouped under three main headings: placing greater emphasis on more contemporary history, promoting the digitization of historical materials to increase access, and enhancing outreach through an exhibition program. 


\section{Placing Greater Emphasis on 20th-Century History}

Dr. Lindberg's interest in history was broad, but he was especially committed to having the Library increase its efforts to document and interpret more recent developments in the health field, specifically those of the 20th century, given the significant developments in medicine and science since World War II and the advancing ages of many key participants. The Library's general collection, of course, covered relevant contemporary printed and electronic materials relatively comprehensively. However, it was the responsibility of the History of Medicine Division (HMD) to collect and house manuscripts and archives and prints and photographs. The Division's audiovisual collections also covered roughly the first three-quarters of the twentieth century. Dr. Lindberg not only encouraged and supported the expansion of these efforts in documenting the 20th century but took an active role in the process. He additionally promoted public programs, research, and publications on recent medical history.

From early in his tenure at the Library, Dr. Lindberg worked with HMD and its Chief, John Parascandola Ph.D., to place increased emphasis on collecting the archival records of important institutions and the personal papers of key scientists and health professionals. Because of his knowledge of contemporary medicine and his many contacts in the field, Dr. Lindberg was able to identify and facilitate the acquisition of relevant collections. He also promoted the recording of the history of contemporary medicine through conferences and publications.

An excellent example of Dr. Lindberg's contributions with respect to institutional history and records is the key role he played in the documentation of the Regional Medical Programs (RMP) initiative. The RMP were conceived as a "Great Society" project of U.S. President's Lyndon B. Johnson's administration and had the goal of bringing high-quality medical care to the American people by linking health research with community health needs on a regional level. Centers of excellence that encompassed medical schools, research institutions, and hospitals were created under the program. The President's Commission on Heart Disease, Cancer and Stroke, chaired by Michael E. DeBakey M.D., produced the blueprint. The RMP became operational in 1966 but began to decline in 1974 due to cuts in the U.S. federal health care budget. Independent RMP operations had ceased by 1976 [1].

Dr. Lindberg was involved with the University of Missouri RMP as a young faculty member and developed several innovative computer applications that contributed to the success of the program. As a result of his experience, Dr. Lindberg came to greatly respect the RMP and always regretted its demise. When he came to the Library, he saw an opportunity to preserve and tell the history of this significant program and the lessons to be learned from it [2].

Based on his own experience and knowledge, in 1991 Dr. Lindberg identified key individuals involved in the development of the RMP and arranged to conduct oral histories to preserve their recollections of the program. With assistance from HMD and the Lister Hill National Center for Biomedical Communications (LHC) Audiovisual Program and Development Branch (APDB), the selected participants were brought to NLM for videotaped interviews, some conducted by Dr. Lindberg himself. The interviews, then, were deposited in the Library's collection. Dr. Lindberg used this opportunity to obtain manuscript materials related to the RMP from the participants to add to NLM's collection [3]. Lois Ann Colaianni M.L.S., then NLM Associate Director for Library Operations, also had previous experience in an RMP program and solicited and compiled documentation of RMP projects involving medical librarians. 
In addition to documenting the RMP, Dr. Lindberg decided that its history should be told in various formats. He arranged for a conference at NLM on the history of the RMP initiative in December of 1991 and for the APDB to produce a video history of the program [4]. He hired historian Steven Strickland Ph.D. to write a history of the RMP. Strickland's The History of Regional Medical Programs: The Life and Death of a Small Initiative of the Great Society was published in 2000 [5].

Not surprisingly, Dr. Lindberg took an active interest in the history of biomedical informatics, the field in which he had a distinguished career. He arranged for the library to host a conference on the history of medical informatics in November 1987 [6]. Dr. Lindberg persuaded another pioneer in the field, Morris F. Collen M.D., to undertake a project on the history of computers in medicine with support from the Library. The result of this effort was Collen's book, A History of Medical informatics in the United States, 1950 to 1990, published in 1995 [7]. Dr. Collen also deposited his personal papers at NLM.

In addition, Dr. Lindberg promoted preserving and providing access to the historical records of health services research, another relatively young research field. Before coming to NLM, Dr. Lindberg directed a National Special Emphasis Center on Health Care Technology at the University of Missouri, funded by the National Center for Health Services Research. The 1993 National Institutes of Health (NIH) Revitalization Act created a National Information Center on Health Services Research and Health Care Technology (NICHSR) at NLM to improve "the collection, storage, analysis, retrieval and dissemination of information on health services research, clinical practice guidelines, and on health care technology" [8].

Dr. Lindberg recognized the importance of documenting the history of this discipline. In 2000, NICHSR and the LHC worked with HMD to produce Health Services Research: A Historical Perspective, a video history of the field. The following year, NICHSR convened an ad hoc advisory committee of health services researchers, historians, and librarians to advise NLM "on appropriate next steps in its initiative to document and preserve the history of health services research" [9].

As aforementioned, Dr. Lindberg encouraged the expansion of the NLM collection of personal papers of contemporary health professionals and biomedical scientists. He took an active role in soliciting these collections. For example, it was Dr. Lindberg who first approached Nobel Laureate Joshua Lederberg on behalf of NLM and persuaded him to contribute his large collection of personal papers to the Library [10]. Lederberg shared the 1958 Nobel Prize in Physiology or Medicine for his discoveries concerning genetic recombination and the organization of the genetic material of bacteria.

Among others, Dr. Lindberg helped NLM acquire the personal papers of Dr. DeBakey and biochemist Dr. Marshall Nirenberg (the National Institutes of Health scientist who shared the Nobel Prize in Physiology or Medicine in 1968 for his work in breaking the genetic code). Dr. Lindberg also promoted increased access to these modern manuscript collections through digitization as discussed in the following section.

Given Dr. Lindberg's interest in visual arts, it is not surprising he also actively supported the expansion of NLM's collection of public health and biomedical posters, especially recent ones. In 1987, HMD began a vigorous campaign to collect contemporary posters, with special emphasis on AIDS, with the aid of consultant William Helfand, an expert on this genre [11]. NLM prepared a traveling exhibition of posters from its collection in 1990 that was eventually circulated to ten museums and medical libraries [12]. 


\section{Digitization of Historical Materials to Increase Access}

Dr. Lindberg recognized it was important not only to collect and preserve the historical record, but also to provide access to it. Given his technical background in computers and medicine, Dr. Lindberg clearly understood that the digitization of library materials was the best way to make them more accessible to users. He initiated and/or supported several important initiatives in this regard.

One highly visible effort was the Profiles in Science project. From the time he first talked to Dr. Joshua Lederberg about donating his personal papers to the Library, Dr. Lindberg envisioned and discussed digitizing these papers so that they might be accessible to remote users [10]. This idea led to the creation of Profiles in Science, a pioneering digital library Web service that "brought together the best in archival practices with state-of-the-art technology to present to the public a look behind the sense of scientific findings and the unpublished writings, letters, and lab notes of great scientists." HMD staff worked with the LHC to establish a production operation for scanning and creating metadata for the manuscripts of important scientists, and the Profiles in Science website debuted in September 1998 [13,p. iv,8.].

Papers related to Dr. Oswald Avery, the scientist at the Rockefeller Institute for Medical Research who provided the first evidence that DNA was hereditary material in the 1940s, were the first to become accessible on the website. The originals of most of the items in this collection are held in other archives, reflecting Dr. Lindberg's view that the Profiles in Science site should include materials held by other institutions. The papers of Dr. Lederberg contained materials related to Avery, including copies of originals in the Rockefeller Archive Center assembled by Dr. Lederberg during his tenure at the Rockefeller Institute. Dr. Lederberg thought that Dr. Avery should have received a Nobel Prize for his work and encouraged NLM to make his papers available first. The other source for the Avery materials was the Tennessee State Library and Archives. The Lederberg papers themselves were the next materials to be made available on the site [13-14,p.4-5,15].

The Profiles in Science site continued to add collections over the years, and now includes papers from 39 different individuals, encompassing materials housed at NLM and at various other archives. Most of the individuals featured are famous scientists, including Nobel-Prize winners such as: Dr. Lederberg; Dr. Christian Anfinsen; Dr. Nirenberg; Dr. Martin Rodbell; Dr. Harold Varmus; and Dr. Barbara McClintock. In addition, the site includes the papers of non-scientists who played key roles in advancing biomedical science and medicine, such as philanthropist-lobbyist Mary Lasker and U.S. Congressman John Fogarty. The papers of such public health leaders as Surgeon General C. Everett Koop M.D. and epidemiologist and public health administrator Dr. Fred Soper also are included on the site. A selection of public health posters has been added [16].

Another important addition to the Profiles in Science site is the collection of Reports of the U.S. Surgeon General. Dr. Parascandola. then the Public Health Service Historian, proposed to Dr. Lindberg that the Library scan all of the Surgeon General's Reports, beginning with the influential 1964 report on smoking and health. Dr. Lindberg readily agreed to Dr. Parascandola's proposal, and NLM's Library Operations (LO) worked with the LHC and the Office of the Surgeon General to identify and scan all retrospective reports and add them to the Profiles site [17,p.11]. The project was expanded to include additional materials, such as images and other documents related to the Office of the Surgeon General [18]. 
Dr. Lindberg also promoted the digitization and creation of machine-readable catalog records for various parts of NLM's historical collection. One significant example is the digitization of items from the prints and photographs collection. This effort began in the mid-1980s with the creation of a pilot videodisk with about 1,000 images and descriptive records of pictures. HMD then worked with the LHC on a project to put the rest of the prints and photographs collection on videodisk and to link the images to online records. An assessment suggested the videodisk technology was expensive and timeconsuming and would not be the best way to distribute the images. So, a decision was made to create a website with the images and records. In 1994, Dr. R.P.C. Rogers of the LHC prepared the first version of the Images from the History of Medicine website [14,p.18] Improvements were later made to the site to allow users to manipulate images in various ways and to download high resolution copies [19-20]. The Images site currently contains digital images and catalog records for more than 70,000 items [21].

Dr. Lindberg launched NLM's digitization of pre-1966 indexing data, with strong encouragement from Dr. DeBakey. Dr. Lindberg believed that it was important to go back to at least the 1940s because there were important advances that came out of World War II and the expanded postwar funding for biomedical research. Thus, the literature was potentially useful for current biomedical research as well as for historical scholarship. Dr. Lindberg asked LO to undertake this task [22].

More than 307,000 citations from the 1964 and 1965 Cumulated Index Medicus were released in a new OLDMEDLINE or OLDMED database in 1996. The 1964 and 1965 citations were converted from machine readable files available from the Deutsches Institut fur Medizinische Dokumentation und Information, then the German MEDLARS Center. Citations from the 1960-63 volumes of Index Medicus were keyboarded and added next. Contracts were awarded to keyboard 1957-59 data from the Current List of Medical Literature, with Lakota Technologies, a Native American organization, receiving the contract for the 1957 data. Eventually records going back to 1946 were added, and all OLDMEDLINE records were incorporated into MEDLINE [23-26].

In general, Dr. Lindberg was supportive of all efforts to digitize materials in the historical collections [22]. One of the most important of these projects was the digitization of the Index-Catalogue of the Library of the Surgeon-General's Office. John Shaw Billings, head of the Surgeon General's Library of the U. S. Army (predecessor of NLM) initiated the publication of a catalog of the Library's holdings (including books, journals, journal articles, dissertations, etc.) in 1880. This massive project required fifteen years just to complete the first series, which ended in 1895. By that time, the Library had added many more titles and a second series began, followed by a third and a fourth. With the fourth series still in progress in the 1950s, the backlog of indexing had become so great that NLM decided to discontinue the publication in favor of producing monthly indexes and quarterly catalogs with annual cumulations. The last volume appeared in 1961, bringing the total to 61 volumes. Index-Catalogue was, and remains, a treasure trove of bibliographic information for historians of medicine, but it was not widely available in libraries and was very time-consuming to search [27].

The American Association for the History of Medicine's (AAHM) Electronic Media Committee initiated the project to digitize the Index-Catalogue. In 1997, the Wellcome Trust and the Burroughs Wellcome Fund awarded grants to support pilots to determine feasibility and to suggest possible conversion approaches. AAHM presented the results to NLM in 1998, and the Library agreed to support the costs of digitization of the data, system software, and free Internet access. The conversion began in 1999 and was completed in 2002. IndexCat, the online version of the Index-Catalogue, contains all of 
the citations in the 61 volumes of the publication, totaling more than 3.7 million references, making this information much more accessible and searchable online $[23,26,28]$.

During Dr. Lindberg's tenure as NLM's Director, many other historical materials were digitized and made available online. For example, by the end of 2010, 107 interviews from HMD's Oral History Collection, consisting of more than 13,000 pages of transcripts and 80 hours of audio content, had been digitized and made available on a new Web interface. Additional interviews continued to be added to the site [29].

Another important project was the digitization of the Food and Drug Administration (FDA) Notices of Judgement Collection, an archive of the federal notices of judgement (a summary of the final outcome of a court case) for manufacturers and products prosecuted under U.S. food and drug law. The Notices of Judgement are useful resources for historical research and can also lead users to a large collection at NLM of the physical evidence used to prosecute each case [30]. NLM also has digitized hundreds of items from its audiovisual collections and made some of them available, along with historical essays about them, on its Medical Movies on the Web site, later renamed Medicine on Screen [31].

Dr. Lindberg was enthusiastic about NLM's collaboration with other institutions on several digitization projects. For example, in 2004 the Library signed a Memorandum of Understanding with the Wellcome Trust and the United Kingdom Joint Information Systems Committee to work together to make thousands of back issues of historically significant biomedical journals freely available in PubMed Central. The agreement included a donation of $\$ 2.2$ million to NLM to support the digitization process, which involved soliciting volumes to digitize from other libraries to avoid any damage to NLM's archival collection [32]. A subsequent agreement with the Wellcome Trust provided an additional $\$ 1.2$ million for digitizing biomedical journal articles, this time using NLM materials [33]. NLM also joined the Medical Library Heritage Project, a cooperative effort (with funding from the Alfred P. Sloan Foundation) to digitize historical materials from the collections of a consortium of libraries. The goal of the project, which began in 2010, was to digitize books and journals documenting the development of American medicine from the 17th to the 20th century.

The NLM units involved in the project were HMD, the Public Services Division, the Technical Services Division, and the Office of Computer and Communications Systems. The project was NLM's first effort to develop in-house capacity to digitize its collections for long term access and preservation [34, p.8,35, p.7].

A final example of the digitization efforts Dr. Lindberg strongly supported is the "Turning the Pages" project, suggested by then-NLM Deputy Director Kent Smith after he viewed the technology at the British Library (BL). HMD and LHC cooperated with the BL to install "Turning the Pages" at NLM in 2001, using the combination of computer animation, high-quality digitized images, and touch screen technology invented by BL to simulate the action of turning the pages of a book. The first book available at NLM that used this technology was Elizabeth Blackwell's beautifully illustrated Curious Herbal, published between 1737 and 1739. Works added to "Turning the Pages" subsequently included Andreas Vesalius' groundbreaking anatomical treatise De Humani Corporis Fabrica (1543) and the Edwin Smith Papyrus (an Egyptian surgical text from about 1600 BC) [36,17,p.18,37,p.16-17]. LHC reimplemented the technology to make "Turning the Pages" available via the Web. The onsite "Turning the Pages" display is a part of the Library's expanded exhibition efforts, the subject of the following section. 


\section{Enhancing Outreach Through an Exhibition Program}

HMD, working with the LHC's APDB, had long developed two or three historical exhibitions a year for the Library's front lobby, displayed in several modest exhibition cases. HMD did not have a dedicated staff to produce these exhibitions, but relied on staff responsible for other activities, often working with outside consultants and organizations. Dr. Lindberg took an interest in these exhibitions from the time that he arrived at NLM. He also saw the potential for outreach that an expanded and improved exhibition program could offer and eventually took implementation steps [10, 22, 38-39].

One of the reasons Elizabeth Fee Ph.D. was hired for the position of Chief of HMD in 1995 was Dr. Lindberg's interest in her experience in developing exhibitions. For example, Dr. Fee recently had served as the co-curator of the highly acclaimed "Garbage! The History and Politics of Trash in New York City" exhibition, on display at the New York Public Library from November 12, 1994 through February 25, 1995 [22, 40-41].

Soon after Dr. Fee arrived at the Library, an opportunity arose for NLM to produce a major exhibition of the type Dr. Lindberg envisioned. Esther Sternberg M.D., then a Senior Scientist and Section Chair at the U.S. National Institute of Mental Health (NIMH), was working with the John D. and Catherine T. MacArthur Foundation on planning an international meeting on the interactions among neurophysiology and the functioning of immune systems. At the time, some sectors of the scientific community were suspicious of the idea of a connection between the brain and the immune system, and between emotions and disease. Yet, the decision was made to hold the Third International Congress of the International Society of Neuroimmunomodulation at the Natcher Center at NIH in November, 1996. Since NLM is just across the street from the Natcher Center, Dr. Sternberg believed it would be an ideal place to hold an opening reception. When she consulted with Sheldon Cohen M.D. of the National Institute of Allergy and Infectious Diseases, then a scientific scholar at NLM, he suggested the Library would also be an excellent venue for an exhibition on the mind-body connection, which had a long history in medicine. Dr. Cohen mentioned NLM had recently hired Dr. Fee, and she was looking for a topic for a planned new exhibition program [40].

Dr. Cohen introduced Dr. Sternberg to Dr. Fee, and the two of them agreed to collaborate on the project, with HMD coordinating the development of the exhibition. Recognizing the demands this project (which had to be completed in several months) placed on HMD staff, Dr. Fee hired Patricia Tuohy, an exhibition specialist, as a shortterm contractor to assist with the exhibition, which opened in October 1996. Historians Dr. Anne Harrington and Dr. Theodore Brown served as visiting curators.

Dr. Lindberg took an active interest in the exhibition, and NLM provided partial support for it. At one point, one of the NIH Institutes strongly objected to the inclusion of a section on Freud because the views discussed were no longer accepted by scientists. Dr. Lindberg firmly resisted efforts to change the exhibition, arguing that the content should accurately portray the history of the subject and one "cannot take Freud out of history." Unlike previous HMD exhibitions, the scope and scale of "Emotions and Disease" and its polished feel resembled a Smithsonian exhibition, and it occupied not just the front lobby, but also the Library's rotunda [22, 40,42-44]. It even garnered a fullpage glowing review in the Weekend Section of the Washington Post [45]. 
Dr. Lindberg reacted enthusiastically and asked Dr. Fee to produce another major exhibition. She extended the contract of Ms. Tuohy to assist with a new exhibition, titled "Frankenstein: Penetrating the Secrets of Nature." Dr. Lindberg was enthusiastic about the topic and behind some of the themes and artifacts selected [22, 44]. The exhibition opened on October 30, 1997 with an opening costume party reception featuring as a special guest Sara Karloff, the daughter of Boris Karloff, who played the monster in the famous 1931 Universal film [46,13,p.12-13]. At the reception, Dr. Lindberg commented: "This thought-provoking exhibit is both timely and timeless. On Halloween eve, its theme is entirely appropriate, of course. But this exhibit explores some of the fundamental questions of all time. Why has the public at times feared science? Have changes in communication technology made the public feel close to the center of decision-making regarding science policy. If so, has this allayed their fear of science?" [46].

Guest curator Dr. Susan Lederer observed: “Unlike in Mary Shelley's day, when access to medical and scientific knowledge was limited to a wealthy and educated elite, today we have unparalleled access to such information through institutions like the National Library of Medicine, through the popular media, and through the World Wide Web. The challenge is how to navigate this ocean of information to educate ourselves about developments in biomedical science, in order to make responsible decisions" [46].

Subsequent exhibitions followed this pattern of being on display for about a year and making use of space in both the front lobby and rotunda. However, HMD continued to mount smaller exhibitions in the front lobby area and within the HMD Reading Room [47]. The next major exhibition, "Breath of Life," about asthma, opened on March 23, 1999. It was the largest exhibition mounted at NLM up to that time. Once again Dr. Lindberg had to run interference when collaborating NIH institutes demurred about the inclusion of empirically falsified ideas - because the latter were needed to complete the exhibition's historical record [22,40,25,p.16].

The pattern of installing a new large-scale exhibition in the rotunda approximately once a year continued and evolved into a formal distinct exhibition program. In 1998, Patricia Tuohy was hired as head of the exhibition program on a permanent basis. The informal exhibition program was officially made a section, the Exhibition Program Section, under a reorganization of HMD in 2008 with Ms. Tuohy as its head [44]. Exhibitions were historically based, but also discussed relevant contemporary aspects of the subjects covered. The description of the program on the NLM website states the goals of the program are to "stimulate enthusiasm for history and encourage people to learn about medicine, themselves, and their communities," "to enhance awareness and appreciation of the NLM's trusted health information resources,' and to "advance public understanding of how the past informs the present - and can shape the future" [48].

Dr. Lindberg continued to play a significant role in various aspects of the exhibition program. For example, he was the prime mover in the selection of some exhibition topics, such as: "The Once and Future Web: Worlds Woven by Telegraph and Internet" (20012002); and "Native Voices: Native Peoples' Concepts of Health and Illness" (October, 2011-July, 2015), which is described by Wood and Siegel [49].

When the "Changing the Face of Medicine: Celebrating America's Women Physicians" exhibition (October 2003-November 2005) was being planned, Dr. Lindberg recognized there could be differences of opinion about which female physicians should be featured. To minimize controversy, Dr. Lindberg arranged for the formation of a distinguished ad hoc advisory committee (both women and men), chaired by surgeon, former Olympic gold medalist, and former NLM Board chair Tenley Albright M.D., who 
had suggested the exhibition topic. The committee included such notable members as Vivien Pinn M.D. (Associate Director for Research on Women's Health, NIH), Senator Barbara Mikulski, Jordan Cohen M.D (President, Association of American Medical Colleges), and Catherine DeAngelis M.D. (Editor, JAMA) [22, 50].

Based on the committee's recommendations, "Changing the Face of Medicine" highlighted a very diverse group of women physicians, so young girls could see doctors who "looked like them" and all attendees could learn about the range of careers open to a person with an M.D. degree [51]. Sixty physicians were featured in displays and more than 300 in an interactive multimedia database. At Dr. Albright's suggestion, visitors were invited to "Share Your Story" about other notable women physicians they had encountered. The American Medical Women's Association collaborated with NLM on a companion "Local Legends" website with profiles of outstanding women physicians nominated by their state's Congressional delegation. Dr. Albright, in a white coat, cut the red ribbon with a scalpel to open the exhibition. Many women featured were there with family and friends.

Dr. Lindberg also actively supported increased outreach for the exhibition program through the development of traveling and online exhibitions. For example, NLM developed a version of the "Frankenstein" exhibition that traveled around the United States under the auspices of the American Library Association [22,52]. This project was the first of many traveling exhibitions. The NIH Office of Research on Women's Health helped sponsor the traveling version of "Changing the Face of Medicine" with its intent to interest girls in medical careers. Many other NLM historical exhibitions also aim to interest students in careers in science, medicine, and information transfer.

Although some traveling exhibitions are based on major exhibitions, most are based on smaller exhibitions developed by NLM and involve roll up displays. The Library makes these displays available free of charge to libraries and other cultural institutions, where they are augmented with local materials and programming [52-54]. The traveling exhibition program has been extremely successful. For instance, in the 2012 fiscal year HMD traveled 25 copies of 12 exhibitions to 156 host venues in 43 states and five international locations [35,p.15].

Dr. Lindberg encouraged the development of online versions of exhibitions to further extend the program's outreach. At the time of this essay's preparation, there were more than 35 exhibitions on NLM's website. Dr. Lindberg also fostered the cooperation between the Library other institutions in the preparation of exhibitions, such as the National Museum of American History, the Folger Shakespeare Library, and Mount Vernon [22, 55-57].

In tribute to Dr. Lindberg's vision with respect to the exhibition Program, HMD Chief Jeffrey Reznick Ph.D. wrote in 2015:

"Perhaps the greatest testimony to Dr. Lindberg's sense of the public value of the Library and its collections is the success of the NLM's award-winning Exhibition Program. Over the last fifteen years, the program has touched millions of individuals through its interactive exhibitions and special displays onsite and on the Web, through its online multidisciplinary K-12 and higher education resources, and most of all, though its traveling exhibitions that tour the world and in so doing inform a wide and diverse audience about stories of the past and their relevance to the present and the future" [58]. 


\section{Conclusion}

This essay has provided an overview of the most important contributions made by Dr. Lindberg to NLM's historical collections and programs. His appreciation for the value of history and its artifacts is reflected in his words in the foreword to the Hidden Treasure: The National Library of Medicine:

"Lastly I take pleasure in echoing the enthusiasm for true, original, real books within our grasp...there are times, especially when we ask why or how a discovery or a belief arose - when we need to see and hold original intellectual works" [59].

\section{Acknowledgements}

I wish to thank the following individuals for providing information that proved useful in the preparation of this essay: Betsy Humphreys, Mary Lindberg, Jeffrey Reznick, Kent Smith, Esther Sternberg, Paul Theerman, and Patricia Tuohy.

\section{References}

[1] Regional Medical Programs. Profiles in science. [Internet] [cited 24 July 2021] https://profiles.nlm.nih.gov/spotlight/rm/feature/briefhistory.

[2] Masys DR. Presentation of the Morris F. Collen Award to Donald A. B. Lindberg, MD. J Am Med Inform Assoc. 1998 Mar-Apr; 5(2): 214-216. DOI: 10.1136/jamia.1995.0050214

[3] National Library of Medicine (US). Board of Regents. Minutes of Board of Regents meeting. January 1992. [Internet] [cited 2021 July 24]. p.4. Available from: https://www.nlm.nih.gov/hmd/manuscripts/nlmarchives/bor/1992.pdf

[4] Audiovisual Program Development Branch, Lister Hill National Center for Biomedical Communications, National Library of Medicine (NLM). Somehow-- some way-- sometime-- , the Regional Medical Programs, 1966-1976; Bethesda, MD: NLM; 1991

[5] Strickland SP. The history of Regional Medical Programs: the life and death of a small initiative of the Great Society; Lanham, MD: University Press of America; c2000.

[6] National Library of Medicine (U.S.). Programs and services fiscal year 1988. [Internet] [cited 2021 July 24] pp. 5,25. Available from: https://www.nlm.nih.gov/ocpl/anreports/fy1988.pdf

[7] Collen MF. A history of medical informatics in the United States, 1950 to 1990; Indianapolis, IN: American Medical Informatics Association; c1996.

[8] National Library of Medicine (U.S.). National Information Center for Health Services Research and Health Care Technology [Internet] [cited 2021 July 24] Available from: https://www.nlm.nih.gov/nichsr/about-NICHSR.html

[9] National Library of Medicine (U.S.). Programs and services fiscal year 2000. [Internet] [cited 2021 June 2] p.20-21. Available from: https://www.nlm.nih.gov/ocpl/anreports/fy2000.pdf

[10] Personal recollection of the author.

[11] National Library of Medicine (U.S.). Board of Regents. Minutes of Board of Regents meeting. June 1989. [Internet] [cited 2021 July 24]. p.11. Available from: https://www.nlm.nih.gov/hmd/manuscripts/nlmarchives/bor/1989.pdf

[12] National Library of Medicine (U.S.). Programs and services fiscal year 1990. [Internet] [cited 2021 June 2] p.14. Available from: https://www.nlm.nih.gov/ocpl/anreports/fy1990.pdf

[13] National Library of Medicine (U.S.). Programs and services fiscal year 1998. [Internet] [cited 2021 June 2] p.iv,8. Available from: https://www.nlm.nih.gov/ocpl/anreports/fy1998.pdf

[14] National Library of Medicine (U.S.). Board of Regents. Minutes of Board of Regents meeting. January 1995. [Internet] [cited 2021 July 24]. p.18. Available from: https://www.nlm.nih.gov/hmd/manuscripts/nlmarchives/bor/Sept1998.pdf

[15] Oswald T. Avery. Profiles in science. [Internet] [cited 2021 July 24] Available from: https://profiles.nlm.nih.gov/spotlight/cc

[16] Profiles in Science. [Internet] [cited 2021 July 24] Available from: https://profiles.nlm.nih.gov/ 
[17] National Library of Medicine (U.S.). Programs and services fiscal year 2002. [Internet] [cited 2021 July 24] p.11. Available from: https://www.nlm.nih.gov/ocpl/anreports/fy2002.pdf

[18] Reports of the Surgeon General. Profiles in Science. [Internet] [cited 2021 July 24] Available from: https://profiles.nlm.nih.gov/spotlight/nn

[19] National Library of Medicine (U.S.). Programs and services fiscal year 2009 [cited 2021 June 2] p.12. Available from: https://www.nlm.nih.gov/ocpl/anreports/fy2009.pdf

[20] [20] Images from the History of Medicine rescanned. [Internet] NLM Newsline 2000 Jan-Mar;55(1). [cited $2021 \quad$ July 24] https://www.nlm.nih.gov/archive/20040423/pubs/nlmnews/janmar00/jm00_rescanned.html

[21] [Images from the History of Medicine. [Internet] [cited 2021 July 24] Available from: https://www.nlm.nih.gov/hmd/ihm/index.html

[22] Personal communication from Betsy Humphreys.

[23] National Library of Medicine (U.S.). Board of Regents. Minutes of Board of Regents Meeting, January 1997. [Internet] [cited 2021 March 23]. p.13. Available from: https://www.nlm.nih.gov/hmd/manuscripts/nlmarchives/bor/Jan1997.pdf

[24] OLDMEDLINE: the newest ELHILL database. NLM Tech Bull 1996 Nov-Dec;293. Available from: https://www.nlm.nih.gov/pubs/techbull/archive/nlm_technical_bulletin_november_december_1996.pdf

[25] OLDMEDLINE data. [Internet] [cited ${ }^{-} 2021{ }^{-}$July $^{-}$24] Available from: https://www.nlm.nih.gov/databases/databases_oldmedline.html

[26] National Library of Medicine (U.S.). Programs and services fiscal year 1999. [Internet] [cited 2021 July 24] p. 11. Available from: https://www.nlm.nih.gov/ocpl/anreports/fy1999.pdf.

[27] Greenberg, SJ, Gallagher, PE. The great contribution: Index Medicus, Index-Catalogue, and IndexCat. J Med Libr Assoc 2009 Apr;97(2):108-13.

[28] IndexCat: Index-Catalogue of the Library of the Surgeon General's Office, 1880-1861. NLM Tech Bull 2004 May-June;338. [cited 2021 July 24] Available from: https://www.nlm.nih.gov/pubs/techbull/mj04/mj04_cat.html

[29] Medical history comes to life through first person accounts in National Library of Medicine digital oral history collections. NLM $\quad$ Tech $\quad$ Bull $2010 \quad$ Nov-Dec.;377. https://www.nlm.nih.gov/pubs/techbull/nd10/nd10_hmd_reprint_oralhistory.html

[30] FDA Notices of Judgment, 1908-1966. [Internet] [cited 2021 July 24] Available from: https://fdanj.nlm.nih.gov/

[31] Medicine on screen. Films and essays from NLM. [Internet [cited 2021 July 24 Available from: https://medicineonscreen.nlm.nih.gov/

[32] International agreement to extend PubMed Central. [Internet] June 24, 2004. [cited 2021 July 24] Available from: https://www.nlm.nih.gov/archive/20120510/news/press_releases/intlpubmed04.html

[33] National Library of Medicine (U.S.). Programs and services fiscal year 2014. [Internet] [cited 2021 June 2]. p.9. Available from: https://www.nlm.nih.gov/ocpl/anreports/fy2014.pdf

[34] National Library of Medicine (U.S.). Programs and services fiscal year 2010. [Internet] [cited 2021 June 2]. Available from: https://www.nlm.nih.gov/ocpl/anreports/fy2010.pdf

[35] National Library of Medicine (U.S.). Programs and services fiscal year 2012. [Internet] [cited 2021 June 2]. Available from: https://www.nlm.nih.gov/ocp1/anreports/fy2012.pdf

[36] National Library of Medicine (U.S.). Board of Regents. Minutes of Board of Regents Meeting, February 2001. [Internet] [cited 2021 July 24]. p.6-8. Available from: https://www.nlm.nih.gov/od/bor/bor201.html

[37] National Library of Medicine (U.S.). Board of Regents. Minutes of Board of Regents Meeting, May 2010. [Internet] [cited 2021 July 24] p.16-17. Available from: https://www.nlm.nih.gov/od/bor/5_2010_BOR.pdf

[38] Personal communication from Kent Smith.

[39] Personal communication from Mary Lindberg.

[40] Personal communication from Esther Sternberg.

[41] Kannapell A. Garbage!: municipal history from the bottom up. NY Times, Nov 13, 1994, sec. 13, p. 3.

[42] Emotions and disease. [Internet] [cited 24 July 2021]. Available from: https://www.nlm.nih.gov/exhibition/emotions/about.html

[43] Personal communication from Patricia Tuohy.

[44] NLM exhibition sheds light on mind-body connection. NLM News 1996 Sep-Dec;52(5-6). https://www.nlm.nih.gov/archive/20040422/pubs/nlmnews/sepdec96.html\#Emotions

[45] Burchard H. Healthy mind, healthy body. Washington Post, Dec 13, 1996, Weekend Section, p. 67.

[46] Frankenstein invades NLM! Exhibit examines monster's many dimensions, relationship to modern $\begin{array}{llll}\text { Medicine. } & \text { NLM } & \text { Newsline } & \text { Sept-Dec;52(5-6). }\end{array}$ https://www.nlm.nih.gov/archive/20040423/pubs/nlmnews/sepdec97.html\#Frankenstein 
[47] National Library of Medicine (U.S.). Programs and services fiscal year 1997. [Internet] [cited 2021 June 2]. pp.13-14. Available from: https://www.nlm.nih.gov/ocpl/anreports/fy1997.pdf

[48] National Library of Medicine (U.S.). History of Medicine Division. About us: Exhibition Program. [Internet] [cited 2021 July 24] Available from: https://www.nlm.nih.gov/hmd/about/exhibition/aboutus.html

[49] Wood FB, Altemus A, Siegel ER. Native Voices exhibition: stories of health, wellness, and illness from American Indians, Alaska Natives, and Native Hawaiians. In: Humphreys BL, Logan RA, Miller RA, Siegel ER, editors. Transforming biomedical informatics and health information access: Don Lindberg and the U.S. National Library of Medicine. Amsterdam: IOS Press; 2021.

[50] Ad Hoc Advisory Group, Changing the face of medicine. [Internet] [cited 2021 July 24] Available from: https://cfmedicine.nlm.nih.gov/adhoc.html

[51] Changing the face of medicine. [Internet] [cited 24 July 2021]. Available from: https://cfmedicine.nlm.nih.gov/

[52] National Library of Medicine (U.S.). Board of Regents. Minutes of Board of Regents Meeting, February 2002. [Internet] [cited 2021 March 23]. p.6. Available from: https://www.nlm.nih.gov/od/bor/bor202.pdf

[53] National Library of Medicine (U.S.). Board of Regents. Minutes of Board of Regents Meeting, September 2014. [Internet] [cited 2021 July 24]. p.6. Available from: https://www.nlm.nih.gov/od/bor/914BORMinutes.pdf

[54] National Library of Medicine (U.S.). History of Medicine Division. Get involved: host NLM traveling exhibitions. [Internet] [cited 2021 July 24]. Available from: https://www.nlm.nih.gov/hmd/getinvolved/hostexhibitions.html

[55] Reznick JS. Perspectives from the History of Medicine Division of the United States National Library of Medicine, National Institutes of Health. Med Hist 2011;55:413-18.

[56] National Library of Medicine (U.S.). Programs and services fiscal year 2013. [Internet] [cited 2021 June 2]. p.14. Available from: https://www.nlm.nih.gov/ocpl/anreports/fy2013.pdf

[57] National Library of Medicine (U.S.). Board of Regents. Minutes of Board of Regents Meeting, February 2013. [Internet] [cited 2021 July 24]. p.7. Available from: https://www.nlm.nih.gov/od/bor/Feb13BORMinutes.pdf

[58] Reznick JS. Donald Lindberg: a leadership legacy for the future. Circulating Now 2015 March 5. https:/circulatingnow.nlm.nih.gov/2015/03/05/donald-lindberg-a-leadership-legacy-for-the-future/

[59] Lindberg, DAB. "Foreword: the National Library of Medicine at 175. In: Sappol, M, editor. Hidden treasure: National Library of Medicine.; New York: Blast Books, c2012, p. 7. 